\title{
Perbandingan Ketepatan Pengukuran Tekanan Balon Pipa Endotrakeal setelah Intubasi antara Metode Palpasi pada Pilot Balon dan Teknik Melepas Spuit secara Pasif
}

\author{
Gunawan Mutiara, ${ }^{1}$ Suwarman, ${ }^{2}$ Ruli Herman Sitanggang ${ }^{2}$ \\ ${ }^{1}$ Rumah Sakit Putera Bahagia Cirebon, ${ }^{2}$ Departemen Anestesiologi dan Terapi intensif \\ Fakultas Kedokteran Universitas Padjadjaran/Rumah Sakit Dr. Hasan Sadikin Bandung
}

\begin{abstract}
Abstrak
Metode palpasi pada pilot balon merupakan teknik yang tidak akurat untuk menentukan tekanan balon pipa endotrakeal (endotracheal tube/ETT). Tujuan penelitian ini membandingkan ketepatan pengukuran tekanan balon ETT antara metode palpasi pada pilot balon (MP) dan teknik melepas spuit secara pasif (MSP). Penelitian dilakukan pada bulan Juni 2014 di Rumah Sakit Dr. Hasan Sadikin Bandung, menggunakan metode kuantitatif eksperimen dengan rancangan uji acak silang tersamar tunggal. Subjek penelitian adalah 94 orang pasien berusia 18-65 tahun dengan status fisik American Society of Anesthesiologists (ASA) IIII, yang menjalani pembedahan dengan anestesi umum secara intubasi endotrakeal. Saat akan dilakukan intubasi, balon ETT dikembangkan dengan dua teknik yang berbeda kelompok metode palpasi $(n=48)$ dan kelompok teknik melepas spuit secara pasif $(n=46)$. Data hasil penelitian dianalisis menggunakan uji-t tidak berpasangan dan uji chi-kuadrat. Hasil penelitian didapatkan tekanan rata-rata pada kelompok MP $57,7 \pm 26,0 \mathrm{cmH}_{2} \mathrm{O}$ dan MSP $28,7 \pm 4,5 \mathrm{cmH}_{2} \mathrm{O}$, sedangkan untuk ketepatan pengukuran pada kelompok MSP $56,5 \%$ dan kelompok MP $6,2 \%(p<0,001)$. Simpulan penelitian ini menunjukkan bahwa metode palpasi merupakan teknik pengukuran tekanan balon ETT yang tidak adekuat.
\end{abstract}

Kata kunci: Metode palpasi pada pilot balon, teknik melepas spuit secara pasif, endotracheal tube

\section{Comparison between Pilot Balloon Palpation Method and Passive Release Technique on the Accuracy of Measurements of Endotracheal Tube Cuff Pressure}

\begin{abstract}
Estimation of cuff pressure by palpating the pilot balloon is not accurate to determine the cuff pressure of endotracheal tube (ETT). Hence, this study we conducted to compare the accuracy of indirect measurements between pilot balloon palpation method (MP) and passive release technique (MSP). This was a single blind randomized crossover study performed in june 2014 at Dr. Hasan Sadikin General Hospital Bandung, in which patients received each technique and as a control group. Subjects were 94 patients aged 18-65 years old with American Society of Anesthesiologists (ASA) physical status I-III who underwent surgery requiring tracheal intubation. These subjects were randomized into two groups. After induction of anesthesia, the cuff was inflated with two different techniques: pilot balloon palpation technique $(\mathrm{n}=48)$ and passive release technique $(\mathrm{n}=46)$. Data were statistically analyzed using independent $\mathrm{t}$-test and chi-square test. The mean cuff pressures of group MP was $57.7 \pm 26.0 \mathrm{cmH}_{2} \mathrm{O}$ and for group MSP was $28.7 \pm 4.5 \mathrm{cmH}_{2} \mathrm{O}$, whereas the precision of measurements in the MSP group was $56.5 \%$ and $6.2 \%$ in the MP group $(\mathrm{p}<0.001)$. It is conclude that the palpation method for cuff inflation are inadequate. Therefore, it is suggested that the endotracheal tube cuff pressure must be kept within the optimal range using a standard manometer.
\end{abstract}

Key words: Endotracheal cuff pressure, passive release technique, pilot balloon palpation method

Korespondensi: Gunawan Mutiara, dr., SpAn, Rumah Sakit Putera Bahagia Cirebon, Jl. Ciremai Raya 114 Cirebon, Tlp 0231-485654, Faks 0231-482328, Mobile 081320225130,Email drgunawan@yahoo.com 


\section{Pendahuluan}

Intubasi endotrakea merupakan standar emas untuk menjaga jalan napas dan memberikan ventilasi. Pada pipa endotrakeal (endotracheal tube/ETT) terdapat balon yang dikembangkan pada bagian distal pipa/ETT untuk menutupi permukaan dalam trakea sehingga mencegah aspirasi cairan lambung dan sekret orofaring ke paru-paru, serta memudahkan pemberian volume tidal yang adekuat. ${ }^{1,2}$

Intubasi endotrakea harus dilakukan secara aman. Proses intubasi ini dapat menyebabkan trauma pada trakea dan juga laring meliputi hematom, laserasi mukosa membran, laserasi otot pita suara, dan subluksasi pada kartilago aritenoid. Salah satu faktor yang menyebabkan kerusakan tersebut adalah penekanan balon ETT terhadap dinding trakea. ${ }^{3,4}$

Tekanan balon ETT dipengaruhi beberapa faktor, yaitu volume udara dalam balon, bahan dasar balon ETT, ukuran balon ETT terhadap diameter trakea, compliance trakea dan balon ETT, serta tekanan intratorakal., ${ }^{5,6}$ Tekanan ini bersifat dinamis untuk menyesuaikan dengan kondisi seperti perubahan pada posisi kepala pasien, edema pada mukosa trakea, elastisitas trakea, dan tekanan saat ventilasi., ${ }^{3,7}$

Tekanan balon ETT harus dipertahankan pada rentang 20-30 $\mathrm{cmH}_{2} 0 .{ }^{7}$ Tekanan udara yang kurang akan mengakibatkan kebocoran udara saat ventilasi tekanan positif dan juga menyebabkan mikroaspirasi ke dalam trakea, terutama kejadian pneumonia pada pasien yang dilakukan ventilasi mekanik dalam waktu lama. Sebaliknya, tekanan udara yang berlebih pada balon ETT akan menyebabkan penekanan dan menyebabkan penurunan perfusi kapiler trakea serta dapat berlanjut pada kerusakan ireversibel pada mukosa trakea. ${ }^{4,8}$ Tekanan balon ETT akan semakin bertambah dengan pemakaian $\mathrm{N}_{2} \mathrm{O}$ selama anestesi umum karena gas $\mathrm{N}_{2} \mathrm{O}$ dapat berdifusi ke dalam balon ETT sehingga menyebabkan peningkatan tekanan balon terhadap trakea. ${ }^{3,5}$

Beberapa teknik telah dipergunakan untuk mengurangi kelebihan tekanan pada balon ETT, yaitu mengembangkan balon ETT dengan volume udara yang telah ditentukan, estimasi dengan metode palpasi mempergunakan jari tangan pada pilot balon, penggunaan volume udara balon minimal yang tidak menyebabkan kebocoran, dan pengukuran secara langsung dengan manometer. ${ }^{3,8}$

Pada praktik sehari-hari, sering digunakan metode palpasi (MP) untuk memperkirakan tekanan balon ETT setelah intubasi. Metode palpasi ini dilakukan dengan mengembangkan balon ETT sampai didapatkan tekanan yang cukup dengan perabaan memakai ujung jari pada pilot balon ETT. Beberapa penelitian menyimpulkan bahwa metode ini mempunyai tingkat ketepatan penilaian yang rendah, bersifat subjektif, dan juga tidak dipengaruhi oleh pengalaman dariahli anestesi. Teknikyang paling akurat dalam mengukur tekanan balon ETT yaitu pengukuran langsung menggunakan manometer, tetapi teknik ini jarang digunakan karena keterbatasan alat yang tidak tersedia. ${ }^{9}$

Sebagai alternatif lain, pengukuran tekanan balon ETT mempergunakan teknik melepas spuit secara pasif (MSP). Beberapa penelitian yang memakai teknik pengukuran ini hanya mendapatkan tekanan balon ETT optimal pada 56-65\% pasien. Pengukuran menggunakan teknik tersebut cukup efektif dan juga mudah dilakukan jika tidak tersedia alat manometer untuk mengukur tekanan balon ETT secara langsung. ${ }^{10,11}$

\section{Subjek dan Metode}

Penelitian ini merupakan penelitian kuantitatif eksperimen dengan rancangan uji acak silang tersamar tunggal (single blind randomized crossover trial). Teknik pengambilan sampel mempergunakanmetodeconsecutiveadmission (sesuai kedatangan pasien), sedangkan ukuran sampel ditentukan dengan mempergunakan rumus besar sampel ukuran rata-rata dari dua populasi independen. Berdasarkan rumus tersebut didapatkan jumlah sampel adalah 43 untuk setiap kelompok perlakuan, kemudian ditambah $10 \%$ dari kemungkinan pengeluaran sampel sehingga jumlah sampel terhadap tiap kelompok adalah 48 orang dan jumlah semua sampel adalah 96 orang.

Penelitian dilakukan di Central Operating 
Theatre (COT) Rumah Sakit Dr. Hasan Sadikin Bandung pada bulan Juni 2014. Kriteria inklusi, adalah pasien yang menjalani pembedahan secara terencana dengan anestesi umum dan intubasi endotrakeal, usia 18-65 tahun, status fisik American Society of Anesthesiologists (ASA) I-III, intubasi oral menggunakan ETT bertekanan rendah. Kriteria eksklusi adalah kelainan anatomi trakea serta operasi gawat darurat. Kriteria pengeluaran yang digunakan adalah pasien yang dilakukan intubasi lebih dari satu kali.

Setelah mendapat persetujuan dari Komite Etik Penelitian Kesehatan Fakultas Kedokteran Universitas Padjadjaran/Rumah Sakit Dr. Hasan Sadikin Bandung, dilakukan kunjungan preoperatif satu hari sebelum operasi dan pasien menandatangani formulir persetujuan (imformed consent) mengenai pembedahan dan penelitian yang akan dilaksanakan.

Semua penderita dipuasakan selama enam jam sebelum operasi dari makanan padat dan dua jam dari air bening. Randomisasi sampel dilakukan memakai blok permutasi, kemudian pasien dibagi menjadi 2 (dua) kelompok, yaitu 48 pasien yang diintubasi menggunakan ETT dengan balon yang dikembangkan memakai metode palpasi pada pilot balon (kelompok MP) dan 48 pasien memakai teknik melepas spuit secara pasif (kelompok MSP).

Saat di ruang operasi pasien dibaringkan terlentang, kemudian dipasang alat pantau dan dicatat data kesadaran, tekanan darah, laju nadi, laju napas, suhu, serta saturasi oksigen. Selanjutnya, dipasang kateter intravena untuk akses cairan infus dan obat-obatan. Penelitian ini mempergunakan ETT merek Bicakcilar ${ }^{\circledR}$ dengan ukuran diameter internal ETT 7,0-7,5 $\mathrm{mm}$ serta menggunakan spuit $10 \mathrm{~mL}$ merek Nipro ${ }^{\circledR}$. Sebelumnya ETT yang akan digunakan diuji terlebih dahulu untuk menilai kebocoran udara pada balon ETT, kemudian balon ETT dikempiskan kembali sampai maksimal.

Sebelum induksi anestesi, pasien diberikan cairan infus Ringer laktat (RL) $10 \mathrm{~mL} / \mathrm{kgBB}$ untuk menggantikan cairan puasa. Kemudian, obat-obatan induksi anestesi diberikan sesuai dengan rencana anestesi terhadap pasien masing-masing. Setelah mencapai kedalaman anestesi, dilakukan laringoskopi dan intubasi menggunakan ETT dengan ukuran pipa yang disesuaikan dengan jari kelingking pasien. Setelah intubasi, balon ETT dikembangkan oleh residen anestesi yang merawat pasien tersebut dan diukur besar tekanan balon ETT dengan metode yang sesuai dengan kelompok masing-masing. Pada kelompok MP, balon ETT dikembangkan dengan memberikan udara sebanyak 5 mL menggunakan spuit ukuran 10 $\mathrm{mL}$ yang terhubung dengan katup threeway dan juga katup ETT. Ketika residen anestesi tersebut melakukan palpasi pada pilot balon, udara ditambahkan ataupun dikurangi sesuai dengan kecukupan tekanan yang dirasakan (oleh residen tersebut) pada saat palpasi, kemudian katup threeway tersebut dikunci. Pada kelompok MSP, balon ETT dikembangkan dengan memberikan udara sebanyak $8 \mathrm{~mL}$ mempergunakan spuit ukuran $10 \mathrm{~mL}$ yang terhubung dengan katup threeway dan katup ETT, kemudian spuit tersebut dilepas sehingga terjadi aliran udara balik secara pasif. Setelah piston spuit berhenti bergerak, katup threeway dikunci.

Pada kedua kelompok tersebut dilakukan pengukuran tekanan balon ETT menggunakan alat ukur manometer dengan cara memutar katup threeway yang telah terhubung dengan manometer. Besar tekanan diukur saat pasien ekspirasi, kemudian hasil pengukuran tersebut dicatat. Apabila tekanan balon ETT setelah diukur terlalu besar atau terlalu kecil, udara di dalam balon akan ditambah atau dikurangi hingga diperoleh tekanan normal $\left(25 \mathrm{cmH}_{2} \mathrm{O}\right)$ pada manometer. Data pasien dicatat dan dikelompokkan berdasarkan nama, usia, jenis kelamin, berat badan, volume, serta tekanan balon ETT.

Pemeliharaan anestesi dilanjutkan sesuai dengan rencana anestesi pada pasien masingmasing. Tekanan balon ETT diukur kembali setiap 30 menit mempergunakan manometer dan tekanan balon diatur dalam batas normal. Setelah operasi selesai pasien diekstubasi dalam keadaan sadar penuh ataupun saat masih tidur dalam. Kemudian, pasien dipindah ke ruang pemulihan untuk diobservasi.

Analisis statistik terhadap hasil penelitian 


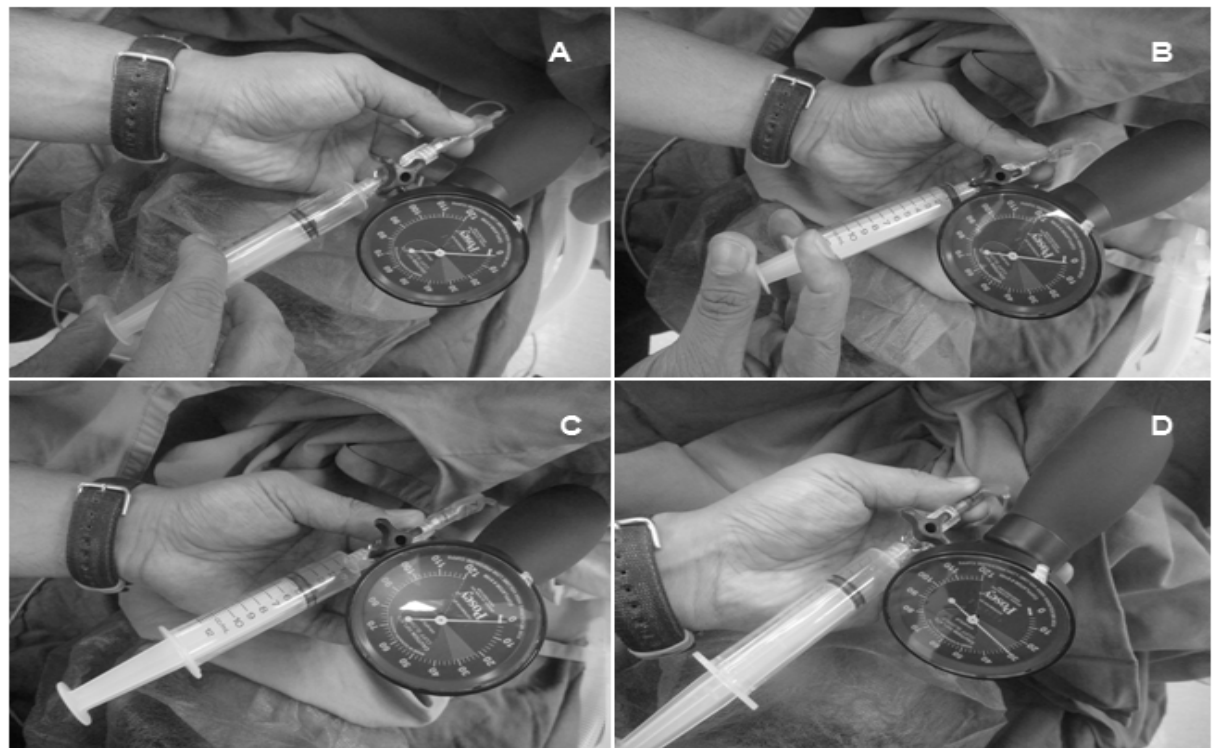

Gambar 1 Perlakuan Kedua Kelompok Penelitian: (A) pada Kelompok MP, Diisi Udara Sebanyak 5 mL, Kemudian Ditambah atau Dikurangi Sambil Melakukan Palpasi pada Pilot Balon, (B) pada Kelompok MSP, Diisikan Udara Sebanyak 8 mL Kemudian Spuit Dilepaskan, (C) Kemudian Terjadi Aliran Balik pada Piston Karet Spuit sampai Berhenti, (D) pada Kedua Kelompok Tersebut, Tekanan Diukur dengan Cara Memutar Katup Three-Way ke Arah Manometer

mempergunakan uji-t tidak berpasangan, chikuadrat, dan Uji Mann-Whitney. Analisis data dilakukan mempergunakan program statistical product and service solutions (SPSS) for windows versi 22.0 pada derajat kepercayaan 95\% dengan nilai $\mathrm{p} \leq 0,05$ dianggap sebagai hasil yang bermakna.

\section{Hasil}

Penelitian dilakukan terhadap 96 pasien yang menjalani pembedahan dengan anestesi umum. Setelah dikurangi oleh subjek yang mengalami drop-out sebanyak 2 (dua) orang, setiap kelompok masing-masing terdiri atas

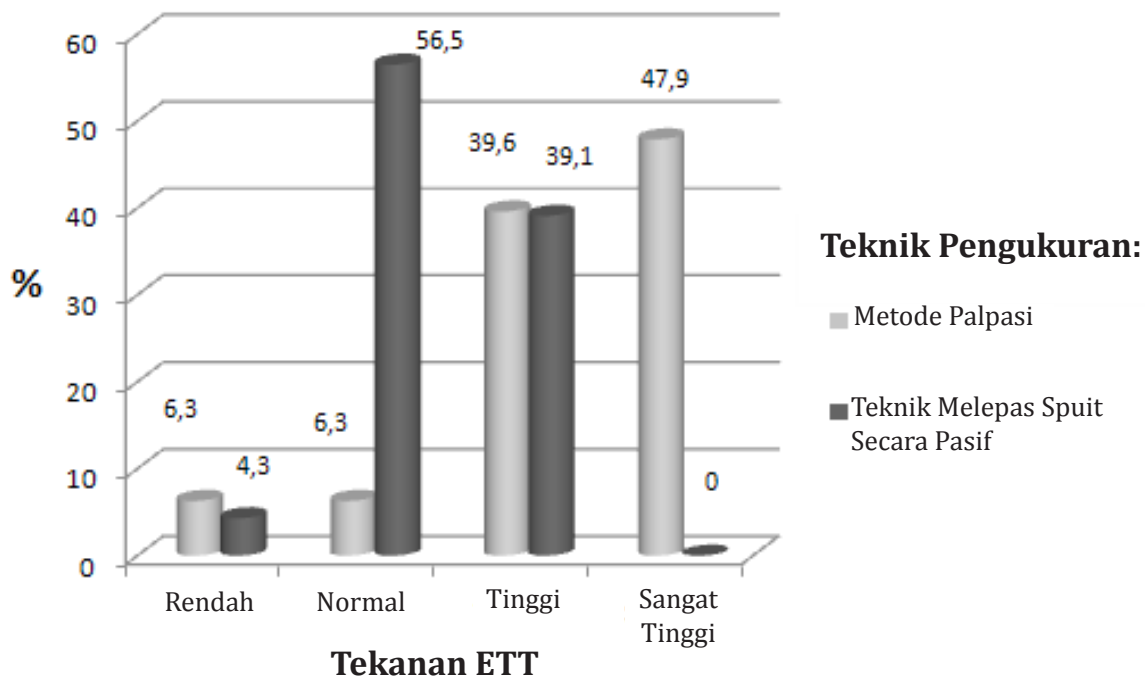

Gambar 2 Distribusi Tekanan Balon ETT pada Kedua Kelompok Perlakuan 
Tabel 1 Karakteristik Umum Subjek Penelitian

\begin{tabular}{lccc}
\hline \multicolumn{1}{c}{ Karakteristik } & $\begin{array}{c}\text { Metode Palpasi } \\
\text { (n=48) }\end{array}$ & $\begin{array}{c}\text { Melepas Spuit } \\
\text { secara Pasif } \\
\text { (n=46) }\end{array}$ & Nilai p \\
\hline Usia (tahun) & $41,97(11,19)$ & $41,21(11,19)$ & \\
$\quad$ Rata-rata (SD) & $41(20-65)$ & $40(18-63)$ & 0,742 \\
$\quad$ Median (rentang) & $17(35,4)$ & $17(37)$ & 0,877 \\
Jenis kelamin & $31(64,6)$ & $29(63)$ & \\
$\quad$ Laki-laki (\%) & $154,75(9,50)$ & $156,63(6,99)$ & 0,124 \\
$\quad$ Perempuan (\%) & $152(134-183)$ & $156(142-170)$ & \\
Tinggi badan (cm) & & & \\
$\quad$ Rata-rata (SD) & $55,66(11,95)$ & $56,23(9,07)$ & 0,508 \\
$\quad$ Median (rentang) & $53,00(37-106)$ & $53,50(45-83)$ & \\
Berat badan (kg) & & & \\
Rata-rata (SD) & $22,95(3,70)$ & $23,00(3,89)$ & 0,949 \\
$\quad$ Median (rentang) & $22,11(17,7-31,6)$ & $22,39(17,6-35,4)$ & \\
Indeks massa tubuh $\left(\mathrm{kg} / \mathrm{m}^{2}\right)$ & & & \\
$\quad$ Rata-rata (SD) & & & \\
$\quad$ Median (rentang) & & & \\
\hline
\end{tabular}

Keterangan: nilai p pada variabel jenis kelamin dihitung berdasar uji chi-kuadrat. Nilai p pada usia dan IMT dihitung berdasarkan uji-t tidak berpasangan. Berat badan dan tinggi badan dihitung berdasarkan Uji Mann-Whitney dikarenakan salah satu kelompok data tidak berdistribusi normal. Nilai p bermakna $(p<0,05)$. SD: standar deviasi/simpangan baku

48 subjek pada kelompok MP dan 46 subjek pada kelompok MSP. Hasil analisis statistik menunjukkan bahwa karakteristik dasar pada kedua kelompok dinyatakan tidak berbeda bermakna ( $p>0,05$; Tabel 1).

Hasil pengukuran nilai tekanan balon ETT rata-rata setelah intubasi ETT didapatkan hasil pengukuran yang lebih besar pada kelompok MP dibanding dengan kelompok MSP dengan perbedaan yang sangat bermakna $(p<0,001$;
Tabel 2).

Ketepatan pengukuran tekanan balon ETT pada kedua kelompok perlakuan dianalisis menggunakan uji chi-kuadrat. Pada kelompok metode palpasi didapatkan hasil pengukuran tekanan normal sejumlah 3 (tiga) sampel (6\%), sedangkan pada kelompok teknik melepas spuit secara pasif diperoleh tekanan normal yang lebih banyak, yaitu 26 sampel (57\%). Berdasarkan pada hasil perhitungan statistika,

Tabel 4 Perbandingan Volume Udara yang Dipompakan ke Dalam Balon

\begin{tabular}{lcccc}
\multicolumn{1}{c}{ Teknik Pengukuran } & $\mathbf{n}$ & $\begin{array}{c}\text { Median } \\
\text { (minimum-maksimum) }\end{array}$ & Rata-rata \pm SD & p \\
\hline Metode palpasi & 46 & $4,6(2,6-6,6)$ & $4,6 \pm 0,9$ & $<0,001$ \\
Teknik melepas spuit secara pasif & 45 & $3,2(2,6-4,6)$ & $3,4 \pm 0,5$ & \\
\hline
\end{tabular}

Keterangan: nilai p dihitung dengan Uji Mann-Whitney dikarenakan salah satu kelompok data tidak berdistribusi normal. SD: standar deviasi/simpangan baku 
Tabel 2 Nilai Tekanan Balon ETT Rata-rata

\begin{tabular}{lcccc}
\hline \multicolumn{1}{c}{ Kelompok } & n & $\begin{array}{c}\text { Rata-rata } \pm \text { SD } \\
\left.\text { (cm } \mathbf{H}_{\mathbf{2}} \mathbf{0}\right)\end{array}$ & $\begin{array}{c}\text { Perbedaan } \\
\text { Rata-rata }\end{array}$ & Nilai p \\
\hline Metode palpasi & 48 & $57,7 \pm 26,0$ & & $<0,001$ \\
Teknik melepas spuit secara pasif & 46 & $28,7 \pm 4,5$ & 29,0 & $<01$ \\
\hline
\end{tabular}

Keterangan: SD: standar deviasi/simpangan baku

Tabel 3 Perbandingan Ketepatan Pengukuran Tekanan Balon ETT

\begin{tabular}{lccccc}
\hline \multirow{2}{*}{\multicolumn{1}{c}{ Teknik Pengukuran }} & \multicolumn{5}{c}{ Jenis Tekanan Balon ETT } \\
\cline { 2 - 5 } & \multicolumn{2}{c}{ Normal } & \multicolumn{2}{c}{ Tidak Normal } & Nilai p \\
\hline Metode palpasi & $\mathbf{n}$ & $\mathbf{\%}$ & $\mathbf{n}$ & $\mathbf{\%}$ & \\
Teknik melepas spuit secara pasif & 3 & 6 & 45 & 94 & $<0,001$ \\
\hline
\end{tabular}

Keterangan: *Nilai p dihitung dengan uji chi-kuadrat

terdapat perbedaan yang sangat bermakna pada kelompok metode palpasi dengan teknik melepas spuit secara pasif ( $\mathrm{p}<0,001$; Tabel 3).

Distribusi tekanan balon dikelompokkan menjadi variabel kategorik berupa tekanan rendah $\left(<20 \mathrm{CmH}_{2} \mathrm{O}\right)$, tekanan normal $(20-30$ $\mathrm{cmH}_{2} \mathrm{O}$ ), tekanan tinggi ( $\geq 30$ dan $<50 \mathrm{cmH}_{2} \mathrm{O}$ ), dan tekanan sangat tinggi $\left(\geq 50 \mathrm{cmH}_{2} \mathrm{O}\right)$. Pada kelompok metode palpasi diperoleh tekanan balon berlebih (overinflation) dengan jumlah yang cukup banyak, yaitu sejumlah 19 sampel (40\%) tekanan tinggi dan 23 sampel (48\%) tekanan sangat tinggi. Pada kelompok teknik melepas spuit secara pasif mempunyai angka overinflation yang lebih sedikit, yaitu 18 sampel (39\%) tekanan tinggi dan tidak ada satupun sampel dengan tekanan sangat tinggi (Gambar 2).
Volume udara yang dipompakan ke dalam balon ETT pada kelompok metode palpasi lebih besar dibanding dengan kelompok MSP dengan perbedaan sangat bermakna $(\mathrm{p}<0,001$; Tabel 4)

Ukuran ETT merupakan variabel perancu terhadap tekanan balon ETT. Pipa endotrakeal yang digunakan pada penelitian ini mempunyai ukuran 7,0 mm dan 7,5 mm. Setelah dilakukan analisis menggunakan uji chi-kuadrat, tidak terdapat perbedaan bermakna di antara kedua kelompok perlakuan (nilai $p>0,05$; Tabel 5).

\section{Pembahasan}

Perbandingan terhadap karakteristik umum antara kedua kelompok perlakuan (Tabel 1) tidak menunjukkan perbedaan yang bermakna

Tabel 5 Ukuran Pipa Endotrakeal

\begin{tabular}{lllll}
\hline \multicolumn{1}{c}{ Ukuran ETT } & $\mathbf{n}$ & \multicolumn{2}{c}{ Ukuran ETT (mm) } & Nilai p \\
\cline { 3 - 4 } & & $\mathbf{7 , 0}$ & $\mathbf{7 , 5}$ & \\
\hline Metode palpasi & 48 & $31(65 \%)$ & $17(35 \%)$ & 0,877 \\
Teknik melepas spuit secara pasif & 46 & $29(63 \%)$ & $17(37 \%)$ & \\
\hline
\end{tabular}

Keterangan: nilai p pada variabel pipa endotrakeal dihitung berdasar uji chi-kuadrat 


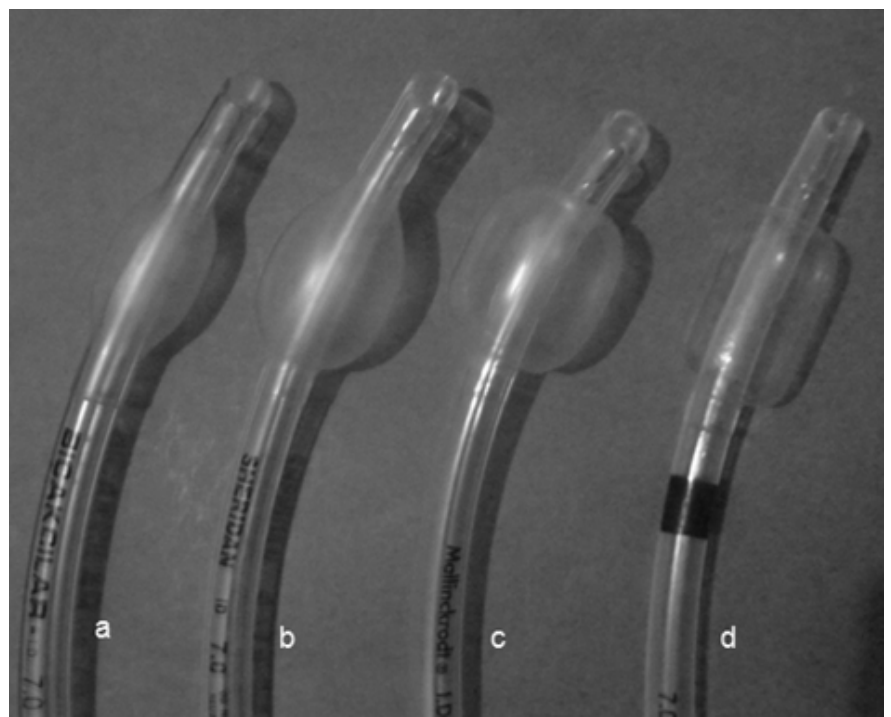

Gambar 3 Perbandingan Ukuran Balon ETT pada Beberapa Merek dengan Ukuran Pipa yang Sama.

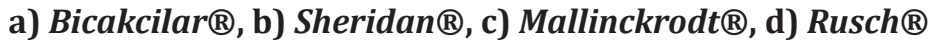

dalam hal usia, jenis kelamin, tinggi badan, berat badan, dan indeks massa tubuh (IMT). Hal ini menunjukkan subjek penelitian telah homogen dan layak untuk diperbandingkan.

Penelitian ini merupakan modifikasi dari penelitian yang dilakukan pada tahun $2010 .^{11}$ Penelitian sebelumnya menggunakan manikin sebagai subjek penelitian, memakai ETT jenis high volume low pressure (HVLP), spuit ukuran $10 \mathrm{~mL}$ dengan merek berbeda, dan pengukuran dilakukan oleh perawat. Pada penelitian kami dilakukan pada objek manusia dengan jumlah sampel yang lebih banyak daripada penelitian sebelumnya, namun jenis ETT yang digunakan adalah ETT dengan volume standar.

Sebelum penelitian ini dilakukan, peneliti melakukan penelitian pendahuluan mengenai volume balon ETT yang akan dipergunakan. Balon ETT dikembangkan dengan memakai udara sebanyak $5 \mathrm{~mL}$ dan ternyata sudah dapat membuat balon ETT tersebut mengembang sempurna. Pada ETT merek lain membutuhkan udara yang lebih banyak dikarenakan volume balon ETT yang lebih besar. Oleh karena itu, pada penelitian ini menggunakan prosedur pengisian udara awal sebanyak $5 \mathrm{~mL}$ pada kelompok MP, sedangkan pada kelompok MSP diberikan pengisian udara yang lebih banyak, yaitu $8 \mathrm{~mL}$ supaya terjadi aliran udara balik.
Pipa endotrakeal dengan merek Bicakcilar ${ }^{\circledR}$ ini memang memiliki volume balon yang lebih rendah bila dibanding dengan ETT merek lain (Gambar 3).

Hasil penghitungan statistika, didapatkan tekanan rata-rata balon ETT pada kelompok MP dan MSP, berturut-turut adalah 57,7 $\pm 26,0$ $\mathrm{cmH}_{2} \mathrm{O}$ dan $28,7 \pm 4,5 \mathrm{cmH}_{2} \mathrm{O}$ dengan perbedaan yang sangat bermakna antara kedua kelompok tersebut $(p<0,001 ;$ Tabel 2). Begitu pula dengan ketepatan pengukuran pada kelompok masing-masing, proporsi tekanan balon yang optimal (nilai normal: 20-30 $\mathrm{cmH}_{2} \mathrm{O}$ ) pada kelompok MSP (57\%) lebih banyak dibanding dengan kelompok MP (6\%). Dengan memakai uji chi-kuadrat didapatkan perbedaan sangat bermakna antara kedua kelompok perlakuan ( $\mathrm{p}<0,001$; Tabel 3).

Distribusi hasil tekanan balon ETT pada penelitian ini dikelompokkan menjadi empat kategori: rendah, normal, tinggi, dan sangat tinggi(Gambar2).Kelompok MP secarastatistik mempunyai ketepatan pengukuran yang lebih sedikit (6\%) dibanding dengan kelompok MSP (57\%). Pada kelompok MP mempunyai angka overinflation yang cukup banyak, sebesar $40 \%$ bertekanan tinggi dan $48 \%$ bertekanan sangat tinggi. Padahal, sebagaimana diketahui sebelumnya bahwa tekanan balon ETT di 
atas $50 \mathrm{cmH}_{2} \mathrm{O}$ merupakan critical perfusion pressure yang akan menyebabkan penghentian aliran darah perfusi darah ke jaringan mukosa cincin trakea dan dinding posteriornya. ${ }^{4}$ Pada kelompok teknik melepas spuit secara pasif mempunyai angka overinflation yang lebih sedikit, yaitu hanya 39\% bertekanan tinggi dan tidak ada satupun sampel dengan tekanan sangat tinggi. Meskipun demikian, pada kedua kelompok mempunyai tekanan underinflation masing-masing sebesar 6\% pada kelompok MP dan 4\% pada kelompok MSP. Sebagai kontrol, ketika menggunakan manometer sebagai alat ukur standar menunjukkan ketepatan sebesar $100 \%$.

Konsep tekanan udara berhubungan dengan jumlah volume udara yang dipompakan di dalam suatu ruang yang tertutup. Begitu pula dengan balon ETT, tekanan akan berbanding lurus secara linier terhadap volume udara yang dipompakan. Ketika volume udara yang diberikan terlalu berlebihan hingga melebihi compliance balon ETT, tekanan akan melonjak drastis secara eksponensial. ${ }^{3,5}$

Pada kelompok MP, pengukuran dilakukan dengan teknik estimasi memakai palpasi jari tangan pada pilot balon. Teknik pengukuran ini akan sangat dipengaruhi oleh sensitivitas reseptor jari tangan ketika melakukan palpasi. Beberapa hasil penelitian menjelaskan bahwa metode ini mempunyai tingkat ketepatan yang rendah, bersifat subjektif, dan juga tidak dipengaruhi oleh pengalaman dokter spesialis anestesi. ${ }^{8,9}$ Hal tersebut dapat dilihat dari hasil penelitian pada kelompok MP, ternyata sensitivitas reseptor jari tangan pada residen anestesi yang melakukan pengukuran hanya mempunyai ketepatan sebanyak 6,3\% dengan tekanan rata-rata balon yang cukup tinggi $\left(57,7 \pm 26,0 \mathrm{cmH}_{2} 0\right)$. Berdasar hasil penelitian sebelumnya, metode palpasi memberikan tekanan normal, yaitu pada batas 20 hingga 30 $\mathrm{cmH}_{2} \mathrm{O}$ sebanyak $24 \%{ }^{8}$

Teknik pengukuran yang paling baik adalah menggunakan alat ukur standar (manometer). Alat ini memungkinkan pengaturan tekanan balon ETT dalam batas normal $\left(20-30 \mathrm{cmH}_{2} \mathrm{O}\right)$ sehingga cara pengukuran ini mempunyai ketepatan yang paling tinggi, meskipun ada perbedaan bias dan juga presisi dari masingmasing unit. Jika tidak tersedia manometer, sebaiknya metode palpasi pada pilot balon tidak dipergunakan lagi karena mempunyai ketepatan yang rendah. ${ }^{12}$ Meskipun demikian, sampai saat ini metode palpasi masih sering dipergunakan karena alasan tidak tersedianya alat dan metode ini sangat praktis karena tidak memerlukan peralatan tambahan.

Sensitivitas jari tangan terhadap tekanan pada metode palpasi dapat dilatih dengan cara sering melakukan palpasi pada pilot balon dengan tekanan normal. Terdapat penelitian yang menunjukkan bahwa latihan palpasi pada pilot balon dengan berbagai tekanan berbeda selama 1 (satu) jam/hari selama 3 (tiga) hari berturut-turut akan meningkatkan sensitivitas ketepatan pengukuran dari hanya $14 \%$ menjadi mendekati $100 \%$. Sensitivitas pengukuran ini akan mulai menurun pada bulan berikutnya sehingga setelah enam bulan perlu dilakukan latihan palpasi balon kembali. ${ }^{13}$ Namun, desain pilot balon dari setiap model ETT juga akan memengaruhi kemampuan residen anestesi dalam memperkirakan tekanan yang optimal. Sensitivitas residen anestesi mungkin akan berbeda jika melakukan palpasi pada merek ETT dengan desain pilot balon yang berbeda. ${ }^{14}$ Pengukurandenganteknikmelepasspuitsecara pasif dilakukan dengan cara memompakan udara dengan spuit ke dalam balon ETT dengan volume yang telah ditentukan, kemudian melepaskan spuit sehingga terjadi aliran udara balik yang bersifat satu arah. Namun, metode ini mempunyai kekurangan, yaitu dipengaruhi oleh ukuran dan desain spuit yang dibuat oleh beberapa pabrik. ${ }^{10}$ Dari penelitian sebelumnya yang menggunakan teknik MSP, dari 95 pasien diperoleh tekanan yang optimal sebanyak $56 \%$ pada kelompok spuit $10 \mathrm{~mL}$ Portex $^{\circledR}$ dan $63,2 \%$ pada kelompok spuit 10 mL Euromed $^{\circledR}$. Pada penelitian tersebut, udara dipompakan sebanyak $12 \mathrm{~mL}$ ke dalam balon ETT merek Portex $^{\circledR}$. Rentang nilai tekanan optimal yang digunakan pada penelitian tersebut adalah 25-40 $\mathrm{cmH}_{2} \mathrm{O}$, sedangkan pada penelitian ini menggunakan nilai normal pada rentang 20$30 \mathrm{cmH}_{2} \mathrm{O}^{10}$

Pada hasil penelitian ini didapatkan volume 
udara yang dipompakan pada kedua kelompok secara statistika terdapat perbedaan yang bermakna ( $p<0,001$; Tabel 4). Volume udara berlebih yang dipompakan pada kelompok MP menyebabkan overinflation, terbukti dengan banyaknya frekuensi tekanan tinggi dan sangat tinggi pada kelompok MP. Pada kelompok MSP, angka kejadian overinflation balon dapat dikurangi karena pada teknik ini kelebihan tekanan akan dibuang melalui aliran balik spuit yang bersifat satu arah. Menurut hukum fisika tekanan suatu fluida di dalam ruang tertutup akan dialirkan ke segala arah dengan sama besar. Aliran tekanan inilah yang akan menggerakkan piston karet spuit sehingga bergerak mundur secara pasif. ${ }^{10,11}$

Penggunakan berbagai macam spuit akan memengaruhi ketepatan pengukuran pada teknik MSP, karena itu disarankan sebaiknya mempergunakan spuit yang berkualitas baik. Penelitian ini memiliki kelemahan, yaitu hanya dapat menunjukkan ketepatan teknik melepas spuit secara pasif, jika mempergunakan spuit baru dengan merek tertentu $\left(\right.$ Nipro $\left.^{\circledR}\right)$, seperti yang dipergunakan dalam penelitian ini. Spuit jenis loss of resistence (LOR) yang digunakan untuk pemasangan kateter epidural juga dapat dipergunakan, tetapi memiliki ketepatan yang lebih rendah. ${ }^{10}$ Pada penggunaan spuit secara berulang kali, mungkin menurunkan resistensi piston karet tabung spuit. Permukaan piston karet yang aus akan menyebabkan penurunan gaya gesek pada dinding bagian dalam spuit sehingga piston akan lebih mudah bergerak yang menyebabkan underinflation. Keadaan yang sama dapat terjadi pula dengan spuit bekas menyuntikkan obat karena piston karet menjadi basah dan resistensi berkurang. Perlu dilakukan penelitian lebih lanjut untuk membahas hal ini.

Faktor pipa endotrakeal harus mendapat perhatian serius supaya tidak menimbulkan bias yang besar pada hasil. Untuk penelitian ini dipilihkan ukuran diameter internal pipa ETT yang diperkirakan paling sesuai untuk subjek masing-masing. Pipa endotrakeal yang dipergunakan masih steril dan juga berasal dari kemasan pabrik yang sama (Bicakcilar ${ }^{\circledR}$ ), sesuai dengan pengadaan alat kesehatan di
Rumah Sakit Dr. Hasan Sadikin Bandung. Ukuran diameter ETT yang dipergunakan pada penelitian ini disesuaikan dengan ukuran jari kelingking pasien dan tidak ada perbedaan bermakna pada ukuran ETT antara kedua kelompok perlakuan (Tabel 5).

Merek ETT yang digunakan pada penelitian ini mempunyai karakteristik volume standar dan bertekanan rendah. Keuntungan ETT jenis ini adalah mempunyai diameter balon yang lebih kecil. Hal tersebut dapat menghindari lipatan pada balon, seperti pada ETT dengan volume tinggi dan juga tekanan rendah (HVLP) saat bersentuhan dengan permukaan trakea sehingga mengurangi kebocoran udara atau aspirasi. Kekurangannya, jika ukuran balon ETT tidak sesuai dengan trakea (lebih kecil) diperlukan tekanan yang lebih tinggi supaya balon ETT tersebut dapat melapisi bagian dalam trakea. Balon ETT dikatakan berukuran tepat jika mampu menutupi bagian di dalam trakea dengan tekanan yang normal (20-30 $\mathrm{cmH}_{2} \mathrm{O}$ ). Ukuran diameter balon ETT minimal sama dengan ukuran trakea, tetapi tidak boleh terlalu besar melebihi 1,5 kali ukuran diameter trakea. ${ }^{3,5}$

Komplikasi yang berhubungan dengan tekanan balon ETT tidak diperiksa dalam penelitian ini. Metode pengukuran estimasi pada kedua kelompok perlakuan diperiksa satu kali setelah intubasi. Pemantauan tekanan balon ETT selanjutnya menggunakan alat ukur standar (manometer) agar tekanan ETT dijaga dalam rentang normal sehingga efek samping akibat overinflation ataupun underinflation juga minimal.

\section{Simpulan}

Metode pengukuran tekanan balon ETT dengan perkiraan tekanan memakai metode palpasi mempunyai tingkat ketepatan yang rendah sehingga tidak disarankan dipergunakan lagi. Apabila tidak tersedia alat ukur standar, dapat dipertimbangkan menggunakan pengukuran lain dengan teknik melepas spuit secara pasif. Teknik ini lebih objektif, sederhana, murah, dan juga mudah diaplikasikan dalam praktik sehari-hari. 


\section{Daftar Pustaka}

1. Baker PA, Timmermann A. Indication for endotracheal intubation. Dalam: Hagberg CA, penyunting. Benumof and Hagberg's airway management. Edisi ke-3. Philadelphia: Saunders; 2013. hlm. 340-5.

2. Henderson J. Airway management in adult. Dalam: Miller RD, Eriksson LI, WienerKronisch JP, Young WL, penyunting. Miller's anesthesia. Edisi ke-7. New York: Churchill Livingstone; 2009. hlm. 1573-610.

3. Abdallah M. Endotracheal tubes cuffs. Durban, South Africa: Departement of Anaesthetics, University of Kwazulu-Natal. 2011.

4. Sultan P, Carvalho B, Rose BO, Cregg R. Endotracheal tube cuff pressure monitoring: a review of the evidence. J Perioper Pract. 2011;21(11):379-86.

5. Efrati S, Deutsch I, Gurman GM. Endotracheal tube-small important part of a big issue. J Clin Monit Comput. 2012; 26(1):53-60.

6. Morgan JE, Mikhail MS, Murray MJ. Airway management. Clinical anesthesiology. Edisi ke-5. New York: McGraw Hill Companies; 2013. hlm. 309-401.

7. Mort TC, Keck Jr JP, Meisterling L. Endotracheal tube and respiratory care. Dalam: Hagberg CA, penyunting. Benumof and Hagberg's airway management. Edisi ke-3. Philadelphia: Saunders; 2013. hlm. 957-80.
8. Ozer AB, Demirel I, Gunduz G, Erhan OL. Effects of user experience and method in the inflation of endotracheal tube pilot balloon on cuff pressure. Niger J Clin Pract. 2013;16(2):253-7.

9. Ghafouri HB, Saeeidi H, Yasinzadeh M, Famaori S, Modirian E. Excessive endotracheal tube cuff pressure: Is there any difference between emergency physicians and anesthesiologists? Sig Vitae. 2012;7(2):17-20.

10. Huh J, Yoon TG, Kwon WK, Joo Y, Kim DK. Usefulness of new technique using a disposable syringe for endotracheal tube cuff inflation. Korean J Anesthesiol. 2009 May;56(5):513-8.

11. Park KC, Sohn YD, Ahn HC, Ahn JY, Park SM, Cho KY, dkk. Effectiveness, preference and ease of passive release techniques using a syringe for endotracheal tube cuff inflation. J Korean Soc Emerg Med. 2010 Dec;21(6):795-800.

12. Blanch PD. Laboratory evaluation of 4 brands of endotracheal tube cuff inflator. Resp Care. 2004;49(2):166-73.

13. Jian YZ, Xia XH, Mei WX. Sensitivity training of residents to pressure improves the management of tracheal tube intracuff pressure. Int J Precis Eng Man. 2011;4:538.

14. Janossy KM, Pullen J, Young D, Bell G. The effect of pilot balloon design on estimation of safe tracheal tube cuff pressure. Anaesthesia. 2010; 65(8):785-90. 